\title{
Determinants of loss of glycemic control in patients with type 1 diabetes mellitus. Prospective cohort study from Iraq
}

\author{
Abbas Ali Mansour ${ }^{1 \dagger^{*}}$, Ahmed AAl-Maliky ${ }^{2 \dagger}$ and Bashar Kasem ${ }^{2+}$ \\ *Correspondence: aambaam@yahoo.com \\ ${ }^{\dagger}$ These authors contributed equally to this work. \\ 'Department of Medicine, Basrah College of Medicine, Basrah, Iraq. \\ ${ }^{2}$ Department of Medicine, Al-Faiha Hospital, Basrah, Iraq.
}

\begin{abstract}
Background: Despite advances in insulin therapeutics during the past 25 years, only a few individuals with type 1 diabetes achieve glycemic control. The aim of this study is to assess the determinants of loss of glycemic control in patients with type 1 diabetes mellitus in Basrah, Iraq.

Methods: The data presented are derived from the Al-Faiha Diabetes Endocrine and Metabolism Center (FDEMC) in Basrah. Eligible patients were those with type 1 diabetes. Follow-up started from August 2008 to the end of February 2012. Seven hundred and forty one patients completed the study.

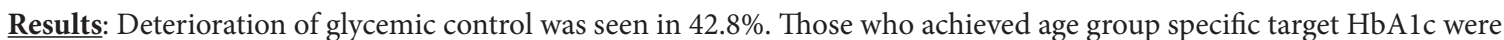
$12.4 \%$. Those with worse glycemic control are younger age ( $21.0 \pm 10.4 \mathrm{vs.} 23.1 \pm 10.9 ; \mathrm{p}=0.01)$, have lower education level (9.45 \pm 2.0 vs. $11.75 \pm 2.6 ; \mathrm{P}=0.01)$ and lower baseline HbA1C percent $(9.45 \pm 2.048$ vs. $11.75 \pm 2.619 ; \mathrm{p}<0.0001)$ than those with more optimal glycemic control.

Conclusion: Factors contributing to worse glycemic control were lower age, less education level, and lower baseline HbA1c. Factors that do not contribute to loss of glycemic control are: gender, number of visits, urban/rural, family history, duration of diabetes, self-monitoring of blood glucose (SMBG) use, Body mass index (BMI) or use of pen for insulin delivery.
\end{abstract}

Keywords: Type 1 diabetes mellitus, glycemic control, HbAlc

\section{Background}

Type 1 diabetes is an immune-mediated disease that develops as a consequence of the gradual destruction of the insulin-producing beta cells, which eventually results in total beta cell loss and complete dependence on exogenous insulin. The disease may present at any age, but the majority of patients are diagnosed before the age of 30 years [1].

More recent data suggests that only about $50-60 \%$ of those with type 1 diabetes are younger than 16-18 years at presentation and that such disease occurs at a low incidence level throughout adulthood [2].

Intensive approaches to management are based on three sentinel observations highlighted by the extensively docu-mented cohort of type 1 diabetes subjects enrolled in the Diabetes Control and Complications Trial (DCCT) and followed in the Epidemiology of Diabetes Interventions and Complications (DCCT/EDIC) study $[3,4]$. These observations were linear relation between $\mathrm{HbA} 1 \mathrm{c}$ and onset or progression of complications, those achieving reduced $\mathrm{HbA1c}$ concentrations, continue to have greater protection against development or progression of complications and there is an inverse relation between glycemic control and the risk of severe hypoglycaemic episodes.

Nonetheless, despite advances in insulin therapeutics during the past 25 years, only a few individuals with type 1 diabetes achieve glycemic control [5].

Diabetes self-care requires a high standard of both initial and continuing education and care, best provided by a multidisciplinary health care team consisting of physicians, nurses, dietitian, and behavioural specialists experienced in the management of type 1 diabetes [6]. Furthermore self-monitoring of blood glucose (SMBG) is fundamental to diabetes care [7].

Approaches with carbohydrate counting to the nutritional management of type 1 diabetes have developed in parallel with basal-bolus insulin regimens [8]. Suboptimal glycemic control that is established during early adolescence may be very difficult to change, even with state-of-the-art behavioural intervention [9].

The aim of this study is to assess the determinants of loss of glycemic control in patients with type 1 diabetes mellitus in Basrah, Iraq.

\section{Patients and methods \\ Data collection}

The data presented are derived from the Al-Faiha Diabetes and Endocrine Center in Basrah. Eligible patients recruited were those with type 1 diabetes. Type 1 diabetes was defined by age at onset of diabetes $<40$ years, C-peptide $\leq 0.3 \mathrm{nmol} / \mathrm{l}$ or insulin treatment initiation within 1 year of diagnosis if C-peptide was not measured or anti-GAD, islet cell or insulin antibodies positive [10-12].

\section{Study procedures}

The patients were visiting the center every 2 months to

(C) 2013 Mansour et al; licensee Herbert Publications Ltd. This is an Open Access article distributed under the terms of Creative Commons Attribution License (http://creativecommons.org/licenses/by/3.0). This permits unrestricted use, distribution, and reproduction in any medium, provided the original work is properly cited. 
Table 1. Clinical and demographic data of 741 patients with type 1 diabetes mellitus.

\begin{tabular}{|c|c|c|}
\hline \multirow{5}{*}{ Age (years) } & $($ mean $\pm \mathrm{SD})$ & $22.2 \pm 10.7$ \\
\hline & Toddlers and preschoolers $(0-6){ }^{\star}$ No. $(\%)$ & $35(4.7)$ \\
\hline & School age (6-12) No.(\%) & $115(15.5)$ \\
\hline & $\begin{array}{l}\text { Adolescents and young adults (13-19) } \\
\text { No.(\%) }\end{array}$ & $192(25.9)$ \\
\hline & Adults (>19) No.(\%) & $399(53.8)$ \\
\hline \multirow[t]{2}{*}{ Gender } & Male No.(\%) & $396(53.4)$ \\
\hline & Female No.(\%) & $345(46.6)$ \\
\hline \multicolumn{2}{|c|}{ Number of visits (mean $\pm \mathrm{SD}$ ) } & $11.0 \pm 5.9$ \\
\hline \multicolumn{2}{|c|}{ Years of academic qualification (mean \pm SD) } & $7 \pm 4.8$ \\
\hline \multicolumn{2}{|c|}{ Rural/urban No.(\%) } & $499(67.3) / 242(32.7)$ \\
\hline \multicolumn{2}{|c|}{ Family history No(\%) } & $445(60.1)$ \\
\hline \multicolumn{2}{|c|}{ Duration of diabetes No(\%) } & $5 \pm 6.2$ \\
\hline \multicolumn{2}{|c|}{${ }^{* *} \mathrm{BMI} \mathrm{kg} / \mathrm{m}^{2} \quad($ mean $\pm \mathrm{SD})$} & $20.41 \pm 4.9$ \\
\hline \multicolumn{2}{|c|}{ ***SMBG No(\%) } & $353(47.6)$ \\
\hline \multicolumn{2}{|c|}{ Baseline HbAlc (mean \pm SD) } & $10.7 \pm 2.6$ \\
\hline \multicolumn{2}{|c|}{ HbA1C Alc at end of the study (mean \pm SD) } & $10.2 \pm 2.6$ \\
\hline \multicolumn{2}{|c|}{ Deterioration of $\mathrm{HbAlc} \mathrm{No( \% )}$} & $317(42.8)$ \\
\hline \multicolumn{2}{|c|}{ Use of pen for insulin delivery No(\%) } & $629(84.9)$ \\
\hline
\end{tabular}

${ }^{\star}$ No. $=$ number

${ }^{* *} \mathrm{BMI}=$ body mass index

$* * * \mathrm{SMBG}=$ self-monitoring of blood glucose

be evaluated and given their treatment free of charge using human insulin only according to standard protocols [13]. Briefly we started with premixed human insulin then added prandial mid day regular insulin. If this approach failed, then Multiple daily injections consisted of neutral protamine Hagedorn insulin were given once or twice daily as the basal insulin, with regular human insulin bolus before meals (basal-bolus approaches). Insulin pumps are still not used in Iraq. At baseline, patients underwent a thorough clinical examination and details of the clinical characteristics of patients were recorded. Details of clinical characteristics of patients, including age at diagnosis of diabetes were taken. Family history was considered only for first degree relatives with diabetes, whether type 1 or type 2 diabetes.

The follow-up started at the time of registration, i.e., from August 2008 continued until the end of February 2012. A total of 1400 patients were enrolled. There was a dropout of 659 and the remaining 741 patients completed the study.

Patients were excluded if the follow up period was less than 6 months pregnant, or having only one reading of $\mathrm{HbA1c}$.

The SMBG was considered as present if the patient did at least one measure a dag. Blood samples for glycosylated hemoglobin (HbA1c) analysis were taken each 3-4 months. Analysis was done using Bio-Rad D10 analyzer (HPLC cation-exchange chromatography).

Age group specific target $\mathrm{HbA1c}$ was according to the recommendation of the ADA [14].

The study was performed according to the criteria of the Helsinki II Declaration and was approved by the
Table 2. HbA1c levels at presentation and end of the study.

\begin{tabular}{|c|c|c|c|c|}
\hline Age group (years) & $\begin{array}{c}{ }^{\star} \mathrm{HbAlc} \text { at } \\
\text { presentation } \\
\text { mean } \pm \text { SD }\end{array}$ & $\begin{array}{c}{ }^{\star} \mathrm{HbAlc} \text { at } \\
\text { end of study } \\
\text { mean } \pm \text { SD }\end{array}$ & $\begin{array}{c}\text { Achieved } \\
\text { target HbAlc } \\
\text { at end of study } \\
\text { No. }(\%)\end{array}$ & $\begin{array}{c}\text { Total } \\
\text { No.(\%) }\end{array}$ \\
\hline $\begin{array}{l}\text { Toddlers and } \\
\text { preschoolers }(1-6)\end{array}$ & $11.0 \pm 1.9$ & $10.2 \pm 2.4$ & $6(17.1)$ & $35(4.7)$ \\
\hline School age (6-12) & $11.2 \pm 2.4$ & $11.4 \pm 2.5$ & $9(7.8)$ & $115(15.5)$ \\
\hline $\begin{array}{l}\text { Adolescents and } \\
\text { young adults } \\
(13-19)\end{array}$ & $11.4 \pm 2.9$ & $10.8 \pm 2.8$ & $25(13.7)$ & $192(25.9)$ \\
\hline adults $(>19)$ & $10.3 \pm 2.5$ & $9.5 \pm 2.3$ & $52(13.0)$ & $399(53.8)$ \\
\hline \multicolumn{5}{|c|}{ HbAlc percent } \\
\hline $\begin{array}{l}<7 \text { No. of patients } \\
(\%)\end{array}$ & $40(5.4)$ & $74(10)$ & - & - \\
\hline $\begin{array}{l}\text { 7-9 No. of patients } \\
(\%)\end{array}$ & $164(22.1)$ & $190(25.6)$ & - & - \\
\hline $\begin{array}{l}\text { 10-11 No. of patients } \\
\text { (\%) }\end{array}$ & $131(17.7)$ & $124(16.7)$ & - & - \\
\hline $\begin{array}{l}\text { 12-13 No. of patients } \\
\text { (\%) }\end{array}$ & $87(11.7)$ & $68(9.2)$ & - & - \\
\hline $\begin{array}{l}\geq 14 \text { No. of patients } \\
(\%)\end{array}$ & $319(43.0)$ & $285(38.5)$ & - & - \\
\hline
\end{tabular}

${ }^{\star} \mathrm{P}$ value between groups $<0.0001$

${ }^{\star *} \mathrm{P}$ value between groups $<0.0001$

local ethical committee. All the patients or their parents/ guardians gave informed consent.

\section{Statistical analysis}

Statistical analysis was carried out using Statistical Package for Social Sciences (SPSS, version 15). Baseline characteristics of the diabetes population were compared using a t-test for continuous variables and a Chi-squared test for dichotomous variables respectively. Means and standard deviations were reported for continuous variables, proportions for dichotomous variables. A p-value of $<0.05$ was taken as statistically significant for individual variables.

\section{Results}

Patient's characteristics are shown in (Table 1). The Age range was 1-64 years. More than half of the patients were adult $>19$ years with number of visits ranging from 2-36 times. Duration of diabetes ranged from 1 to 30 years. Family history of diabetes mellitus was present in $60.1 \%$. SMBG was used by $47.6 \%$. Baseline mean $( \pm$ SD) HbA1c $10.7 \pm 2.6$ percent compared to $10.2 \pm 2.6 \%$ at the end of follow up. Deterioration of glycemic control was seen in $42.8 \%$. A pen to deliver insulin (NovoPen 3 ) was used by $84.9 \%$.

Different ranges of HbA1c are shown in (Table 2). At inclusion, $5.4 \%$ have $\mathrm{HbA} 1 \mathrm{c}<7 \%$ compared to $10 \%$ at the end of follow up; while $43.0 \%$ have an extremely high $\mathrm{HbA1c}(\geq 14 \%)$ compared to $38.5 \%$ at the end of the study.

Outcomes of groups are shown in (Table 3). The study population was divided into two groups; group one with increased $\mathrm{HbA1c}$ and group two with improved HbA1c or no change. Group one constituted 317 (42.8\%) patients. Variables associated with group one were age, education 
Table 3. Variables associated with deterioration of glycemic control.

\begin{tabular}{|c|c|c|c|c|}
\hline & & $\begin{array}{l}\text { Deterioration of } \\
\text { HbA1c (group one) } \\
\mathrm{N}=317(42.8)\end{array}$ & $\begin{array}{l}\text { Improved HbAlc or } \\
\text { no changes } \\
\text { (Group two) } \\
\mathrm{N}=424(57.2)\end{array}$ & P value \\
\hline \multicolumn{2}{|c|}{ Age years $($ mean $\pm \mathrm{SD})$} & $21.0 \pm 10.4$ & $23.1 \pm 10.9$ & 0.011 \\
\hline \multirow[t]{2}{*}{ Gender } & Male No.(\%) & $176(55.5)$ & $220(51.9)$ & 0.3 \\
\hline & Female No.(\%) & $141(44.5)$ & $204(48.1)$ & - \\
\hline \multicolumn{2}{|c|}{ No. of visits } & $11.52 \pm 5.4$ & $10.65 \pm 6.2$ & 0.05 \\
\hline \multicolumn{2}{|c|}{$\begin{array}{l}\text { Years of academic } \\
\text { qualification }\end{array}$} & $6.5 \pm 4.9$ & $7.4 \pm 4.8$ & 0.015 \\
\hline \multicolumn{2}{|c|}{ Rural/urban No. (\%) } & $213(67.2)$ & $286(67.5)$ & 0.9 \\
\hline \multicolumn{2}{|c|}{ Family history No. (\%) } & $203(64.0)$ & $242(57.1)$ & 0.056 \\
\hline \multicolumn{2}{|c|}{$\begin{array}{l}\text { Duration of diabetes } \\
(\text { mean } \pm \text { SD) }\end{array}$} & $4.9 \pm 5.8$ & $5.1 \pm 6.5$ & 0.597 \\
\hline \multicolumn{2}{|c|}{ SMBG No.(\%) } & $150(47.3)$ & $203(47.9)$ & 0.8 \\
\hline \multicolumn{2}{|c|}{$\begin{array}{l}\text { Baseline Alc HbAlc } \\
(\text { mean } \pm \text { SD })\end{array}$} & $9.4 \pm 2.0$ & $11.7 \pm 2.6$ & $<0.0001$ \\
\hline \multicolumn{2}{|c|}{$\begin{array}{l}\text { HbAlc at end of the } \\
\text { study (mean } \pm S D)\end{array}$} & $11.6 \pm 2.5$ & $9.1 \pm 2.2$ & $<0.0001$ \\
\hline \multicolumn{2}{|c|}{$\mathrm{BMI}($ mean $\pm \mathrm{SD})$} & $20.4 \pm 4.9$ & $20.4 \pm 5$ & 0.970 \\
\hline \multicolumn{2}{|c|}{$\begin{array}{l}\text { Use of pen for insulin } \\
\text { delivery No.(\%) }\end{array}$} & $271(85.5)$ & $358(84.4)$ & 0.69 \\
\hline
\end{tabular}

level, baseline and last $\mathrm{HbA1c}$. The mean age in group one was less then group two ( $21.0 \pm 10.4$ vs. $23.1 \pm 10.9 ; p=0.01)$. The education level was lower in group one $(9.45 \pm 2.0 \mathrm{vs}$. $11.75 \pm 2.6 ; \mathrm{P}=0.01)$. Baseline $\mathrm{HbA1c}$ was lower in group one compared with those with group two $(9.45 \pm 2.048$ vs. 11.75 $\pm 2.619 ; \mathrm{p}<0.0001)$. At the end $\mathrm{HbA} 1 \mathrm{c}$ was lower in group two $(9.14 \pm 2.221$ vs. $11.64 \pm 2.500 ; p<0.0001)$. No significant differences were seen between the two groups regarding gender, number of visits, urban/rural, family history, duration of diabetes, SMBG use, Body mass index (BMI), use of pen for insulin delivery.

\section{Discussion}

At the end of follow up, the age specific target $\mathrm{HbA1c}$ was achieved in only $12.4 \%$, while $38.5 \%$ had $\mathrm{HbA} 1 \mathrm{c} \geq 14 \%$. A lot of published series have shown that glycemic control is still often poor in many children with Type 1 diabetes mellitus despite easier home monitoring of blood glucose, the introduction of pen devices for insulin injection, and the introduction of new insulin types and regimens during the last decade $[15,16,18,19$ and 20$]$.

Fewer than $15 \%$ of children and young people with diabetes in England and Wales achieve an HbA1c of $<7.5$ and this figure remains essentially unchanged over the seven year period of follow up and $30.68 \%$ of them have very high $\mathrm{HbA1C}$ ( $\mathrm{HbA1c}$ of $>9.5 \%$ ) [21].

In this study, adults achieved a better reduction in $\mathrm{HbA1C}$ than younger patients, but the achievement of target age specific HbA1c was not different. While in the King Abdul-Aziz University Hospital study younger children had a better control compared to adolescents [16]. In Welsh children with type 1 diabetes glycemic control was worse in children aged $>10$ years [22].

Gender had no effect on outcome this study, which was the same finding seen in King Abdul-Aziz University Hospital study and pediatric diabetes units in Wales $[16,22]$, while in patients with type 1 diabetes mellitus referred to endocrinology clinic in children's hospital medical center in Tehran, Iran, the mean HbA1c was higher in females [23].

Duration of diabetes did not affect the glycemic control in our study in contrary to King Abdul-Aziz University Hospital study where patients with a duration of diabetes $<2$ years had better metabolic control than those with a longer duration [16].

In our study the education level was higher in those with improved glycemic control. Studies conducted on children and adolescents with Type 1 diabetes mellitus have demonstrated that both patient and family education were associated with a reduction in number of hospitalizations, emergency room visits, and a reduction in overall healthcare expenses $[24,25]$.

\section{Conclusion}

Of patients with type 1 diabetes, only $12.4 \%$ achieved age group specific target HbA1c. Worsening of glycemic control (increase of $\mathrm{HbA1c}$ ) while on treatment was seen in $42.8 \%$. Factors contributing to worse glycemic control were younger age, low education level, and lower baseline HbA1c.

\section{Study limitation}

The daily frequency of SMBG was not studied, we acknowledge that the mere presence of SMBG does not guarantee that the patient is using it.

The socioeconomic status of family and educational background of parents also need to be studied, because it could have a role in metabolic control [19]. Medical nutritional therapy is not feasible in Iraq yet, which could contribute to poor outcome.

\section{Competing interests}

The authors declare that they have no competing interests.

\section{Authors' contributions}

Mansour AA, Al-Maliky AA were involved in the concept and design of the study. All authors were involved in the data collection and/or analysis, interpretation of the results and conclusion.

\section{Acknowledgement}

The author is thankful to the staff of of Al-Faiha Diabetes Endocrine and Metabolism Center (FDEMC) in Basrah for their contributions.

\section{Publication history}

Received: 22-Dec-2012 Revised: 02-Mar-2013

Accepted: 20-Apr-2013 Published: 18-May-2013

\section{References}

1. Knip M: Descriptive epidemiology of type 1 diabetes--is it still in? Diabetologia 2012, 55:1227-30. | Article I PubMed

2. Barker JM, Barriga KJ, Yu L, Miao D, Erlich HA, Norris JM, Eisenbarth GS and Rewers M: Prediction of autoantibody positivity and 
progression to type 1 diabetes: Diabetes Autoimmunity Study in the Young (DAISY). J Clin Endocrinol Metab 2004, 89:3896-902. | Article I PubMed

3. The Diabetes Control and Complication Trial Research Group: The effect of intensive treatment of diabetes on the development and progression of long-term complications in insulin-dependent diabetes mellitus. The Diabetes Control and Complications Trial Research Group. N Engl J Med 1993, 329:977-86. | Article I PubMed

4. White NH, Cleary PA, Dahms W, Goldstein D, Malone J and Tamborlane WV: Beneficial effects of intensive therapy of diabetes during adolescence: outcomes after the conclusion of the Diabetes Control and Complications Trial (DCCT). J Pediatr 2001, 139:804-12. I Article I PubMed

5. Chase HP, Dixon B, Pearson J, Fiallo-Scharer R, Walravens $P$, Klingensmith G, Rewers M and Garg SK: Reduced hypoglycemic episodes and improved glycemic control in children with type 1 diabetes using insulin glargine and neutral protamine Hagedorn insulin. J Pediatr 2003, 143:737-40. | Article | PubMed

6. Keers JC, Groen H, Sluiter WJ, Bouma J and Links TP: Cost and benefits of a multidisciplinary intensive diabetes education programme. $J$ Eval Clin Pract 2005, 11:293-303. | Article | PubMed

7. Bui $\mathrm{H}$, Perlman $\mathrm{K}$ and Daneman D: Self-monitoring of blood glucose in children and teens with diabetes. Pediatr Diabetes 2005, 6:50-62. | Article | PubMed

8. Franz MJ, Bantle JP, Beebe CA, Brunzell JD, Chiasson JL, Garg A, Holzmeister LA, Hoogwerf B, Mayer-Davis E, Mooradian AD, Purnell $J Q$ and Wheeler M: Evidence-based nutrition principles and recommendations for the treatment and prevention of diabetes and related complications. Diabetes Care 2002, 25:148-98. | Article I PubMed

9. Hood KK, Peterson CM, Rohan JM and Drotar D: Association between adherence and glycemic control in pediatric type 1 diabetes: a metaanalysis. Pediatrics 2009, 124:e1171-9. | Article | PubMed

10. Lithovius R, Harjutsalo V, Forsblom C and Groop PH: Cumulative cost of prescription medication in outpatients with type 1 diabetes in Finland. Diabetologia 2011, 54:496-503. | Article | PubMed

11. Type 2 Diabetes Practical Targets and Treatments. Asian-Pacific Type 2 Diabetes Policy Group. Fourth edition. 2005. I Pdf

12. Definition, Diagnosis and Classification of Diabetes Mellitus and its Complications. World Health Organization Department of Noncommunicable Disease Surveillance. Geneva. 1999. I Pdf

13. Daneman D: Type 1 diabetes. Lancet 2006, 367:847-58. | Article

14. Standards of medical care in diabetes--2012. Diabetes Care 2012, 35 Suppl 1:S11-63. | Article I PubMed

15. Olsen BS, Sjolie A, Hougaard P, Johannesen J, Borch-Johnsen K, Marinelli K, Thorsteinsson B, Pramming S and Mortensen HB: A 6-year nationwide cohort study of glycaemic control in young people with type 1 diabetes. Risk markers for the development of retinopathy, nephropathy and neuropathy. Danish Study Group of Diabetes in Childhood. J Diabetes Complications 2000, 14:295-300. | Article I PubMed

16. Al-Agha A, Ocheltree A and Hakeem A: Metabolic control in children and adolescents with insulin-dependent diabetes mellitus at King Abdul-Aziz University Hospital. J Clin Res Pediatr Endocrinol 2011, 3:202-7. | Article | PubMed Abstract | PubMed Full Text

17. Mohammadi H, El Malki A, Hassar M, Bouchrif B, Qarbal F, Dahbi F: Glycemic Control, HbA1c, and Lipid Profile in Children with Type 1 Diabetes Mellitus . European Journal of Scientific Research. 2009, 29:289-94.

18. Nawal F Al-Shamali, Khalda, I Al-Qallaf, Haifaa Y Jaafa and Medhat $K$ El-Shazly: Clinical profile and medical care of type w1 diabetics in Kuwait. Alexandria Journal of Medicine 2009, 45:157-66. | Article

19. Gomes MB, Coral M, Cobas RA, Dib SA, Canani LH, Nery M, de Freitas MC, Faria M, Felicio JS, da Silva SC, Pedrosa H, Costa e Forti A, Rea RR, Pires AC, Montenegro Junior R, Oliveira JE, Rassi N and Negrato CA: Prevalence of adults with type 1 diabetes who meet the goals of care in daily clinical practice: a nationwide multicenter study in Brazil. Diabetes Res Clin Pract 2012, 97:63-70. I Article I PubMed
20. Wills CJ, Scott A, Swift PG, Davies MJ, Mackie AD and Mansell P: Retrospective review of care and outcomes in young adults with type 1 diabetes. BMJ 2003, 327:260-1. | Article | PubMed Abstract | PubMed Full Text

21. National Diabetes Paediatric Audit Report 2009-2010.

22. O'Hagan M and Harvey JN: Glycemic control in children with type 1 diabetes in wales: influence of the pediatric diabetes specialist nurse. Diabetes Care 2010, 33:1724-6. | Article | PubMed Abstract | PubMed Full Text

23. Setoodeh A, Mostafavi $F$ and Hedayat T: Glycemic control in Iranian children with type 1 diabetes mellitus: effect of gender. Indian J Pediatr 2012, 79:896-900. | Article | PubMed

24. Beck JK, Logan KJ, Hamm RM, Sproat SM, Musser KM, Everhart PD, McDermott HM and Copeland KC: Reimbursement for pediatric diabetes intensive case management: a model for chronic diseases? Pediatrics 2004, 113:e47-50. | Article | PubMed

25. Svoren BM, Butler D, Levine BS, Anderson BJ and Laffel LM: Reducing acute adverse outcomes in youths with type 1 diabetes: a randomized, controlled trial. Pediatrics 2003, 112:914-22. | Article | PubMed

\section{Citation:}

Mansour AA, Aal-Maliky A and Kasem B: Determinants of loss of glycemic control in patients with type 1 diabetes mellitus. Prospective cohort study from Iraq. Journal of Diabetes Research and Clinical Metabolism 2013, 2:21. http://dx.doi.org/10.7243/2050-0866-2-21 